University of Nebraska - Lincoln

DigitalCommons@University of Nebraska - Lincoln

Agronomy \& Horticulture -- Faculty Publications

Agronomy and Horticulture Department

2010

\title{
Dryland Performance of Sweet Sorghum and Grain Crops for Biofuel in Nebraska
}

Charles S. Wortmann

University of Nebraska-Lincoln, cwortmann2@unl.edu

Adam Liska

University of Nebraska-Lincoln, aliska2@unl.edu

Richard B. Ferguson

University of Nebraska-Lincoln, rferguson1@unl.edu

Drew J. Lyon

University of Nebraska--Lincoln, drew.lyon@wsu.edu

R. N. Klein

University of Nebraska-Lincoln, robert.klein@unl.edu

See next page for additional authors

Follow this and additional works at: https://digitalcommons.unl.edu/agronomyfacpub

Part of the Plant Sciences Commons

Wortmann, Charles S.; Liska, Adam; Ferguson, Richard B.; Lyon, Drew J.; Klein, R. N.; and Dweikat, Ismail M., "Dryland Performance of Sweet Sorghum and Grain Crops for Biofuel in Nebraska" (2010). Agronomy \& Horticulture -- Faculty Publications. 387.

https://digitalcommons.unl.edu/agronomyfacpub/387

This Article is brought to you for free and open access by the Agronomy and Horticulture Department at DigitalCommons@University of Nebraska - Lincoln. It has been accepted for inclusion in Agronomy \& Horticulture -Faculty Publications by an authorized administrator of DigitalCommons@University of Nebraska - Lincoln. 


\section{Authors}

Charles S. Wortmann, Adam Liska, Richard B. Ferguson, Drew J. Lyon, R. N. Klein, and Ismail M. Dweikat 


\title{
Dryland Performance of Sweet Sorghum and Grain Crops for Biofuel in Nebraska
}

\author{
C. S. Wortmann,* A. J. Liska, R. B. Ferguson, D. J. Lyon, R. N. Klein, and I. Dweikat
}

\begin{abstract}
Sweet sorghum [SS; Sorghum bicolor (L.) Moench] is a potential biofuel crop for the Great Plains. Sweet sorghum was compared with corn [Zea mays (L.)] and grain sorghum for potential ethanol yield, energy use efficiency, and greenhouse gas (GHG) emissions at seven dryland site-years in Nebraska. Seasonal rainfall ranged from approximately 340 to $660 \mathrm{~mm}$. Soils were deep with medium texture at all site-years. The effects of seeding rate, $\mathrm{N}$ rate, and cultivar on SS performance were evaluated. Sweet sorghum sugar yield was not affected by seeding rate and $\mathrm{N}$ application at six of seven site-years, but yield was increased by $19 \%$ at one site-year. Calculated ethanol yield and net energy yield were 33 and $21 \%$ more, respectively, with the grain crops compared with SS, but mean net energy yield of an earlier-maturing SS cultivar was comparable with the grain crops. The mean ratio of energy produced in ethanol per total energy invested was $23 \%$ less for grain crops compared with SS. Mean life cycle GHG emissions were $53 \%$ and 66 to $69 \%$ less compared with gasoline for SS and grain crops, respectively. Very efficient use of the ethanol coproducts was assumed for the grain crops while SS bagasse was assumed to be returned to the field. At least one SS cultivar is competitive with grain crops for some biofuel criteria, but SS is not competitive with grain crops for total or net liquid transportation fuel produced per hectare.
\end{abstract}

CWEET SORGHUM is a sugar crop with biofuel poten-

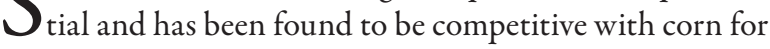
theoretical ethanol yield with less energy invested (Smith et al., 1987; Smith and Buxton, 1993; Hunter and Anderson, 1997). Ethanol production from sugar does not require energy to depolymerize carbohydrates, as is required for grain starch. Smith et al. (1987) reported total sugar yield of SS ranging from 4 to $10.7 \mathrm{Mg} \mathrm{ha}^{-1}$ for the continental United States and up to $12 \mathrm{Mg} \mathrm{ha}^{-1}$ for Hawaii, while Smith and Buxton (1993) reported sugar yields at $6 \mathrm{Mg} \mathrm{ha}^{-1}$ in Iowa and Colorado. Vermerris et al. (2007) reported total sugar concentrations of the juice ranging from 9 to $15 \%$. Ricaud et al. (1979) found sugar concentration in juice at the grain soft dough stage (Warrick, 2009) to range from 12.8 to $16.6 \%$. Calculated ethanol yield estimates for SS have generally ranged from 3000 to $4000 \mathrm{~L}$ $\mathrm{ha}^{-1}$ (Lueschen et al., 1991), with one report estimating the ethanol yield potential to be as high as $8000 \mathrm{~L} \mathrm{ha}^{-1}$ (Hunter and Anderson, 1997). This amount is equivalent to ethanol produced from approximately $20 \mathrm{Mg} \mathrm{ha}^{-1}$ of corn grain.

279 Plant Sci., Univ. of Nebraska, Lincoln, NE 68583-0915. A contribution of the Univ. of Nebraska Agric. Res. Div. supported in part by funds provided through the Hatch Act. Additional support was provided by the U.S. Agency for International Development, under the terms of grant No. LAG-G-00-96-900009-00 to the International Sorghum and Millet Collaborative Research Support Program (INTSORMIL). Received 8 July 2009. ${ }^{*}$ Corresponding author (cwortmann2@unl.edu).

Published in Agron. J. 102:319-326 (2010)

Published online 11 Dec. 2009

doi:10.2134/agronj2009.0271

Copyright $(\odot) 2010$ by the American Society of Agronomy, 677 South Segoe Road, Madison, WI 53711. All rights reserved. No part of this periodical may be reproduced or transmitted in any form or by any means, electronic or mechanical, including photocopying, recording, or any information storage and retrieval system, without permission in writing from the publisher.
Biomass yield from SS has been found to be similar across a wide plant population range (Lueschen et al., 1991; Ferraris and Charles-Edwards, 1986). Sucrose concentration in the juice was $7 \%$ less but fermentable sugar yield was $14 \%$ more with a plant population of 140,000 compared with 70,000 plant ha ${ }^{-1}$ (Broadhead and Freeman, 1980), and water soluble carbohydrate yield was greater with 160,000 compared with 80,000 plant ha ${ }^{-1}$ (Martin and Kelleher, 1984).

Response to applied $\mathrm{N}$ has varied with location. Nitrogen rate did not affect fermentable sugar yield (Smith and Buxton, 1993), total and stalk dry matter yield at harvest (Barbanti et al., 2006), or fermentable carbohydrate and ethanol yield (Lueschen et al., 1991). In Louisiana, biomass yield has been shown to increase by $140 \%$ with application of $100 \mathrm{~kg} \mathrm{ha}^{-1} \mathrm{~N}$, but yield was not increased with an additional $100 \mathrm{~kg} \mathrm{ha}^{-1} \mathrm{~N}$ (Ricaud and Arenneaux, 1990). In the same study, total sugar yield was increased by $150 \%$ by applying $100 \mathrm{~kg} \mathrm{ha}^{-1} \mathrm{~N}$, with an increase of only $4 \%$ from an additional $100 \mathrm{~kg} \mathrm{ha}^{-1} \mathrm{~N}$. Sweet sorghum has been found to require approximately $36 \%$ of the fertilizer $\mathrm{N}$ needed for similar ethanol yield levels in corn (Geng et al., 1989). Total dissolved solid concentration in stalk juice was shown to decrease with increased $\mathrm{N}$ rate (Wiendenfeld, 1984).

Life cycle GHG emissions are restricted for biofuels under the Energy Independence and Security Act of 2007 (available at http://frwebgate.access.gpo.gov/cgi-bin/getdoc. cgi?dbname=110_cong_bills\&docid=f:h6enr.txt.pdf, verified 3 Dec. 2009). Advanced biofuels need to have $>50 \%$ reduction in GHG emissions relative to gasoline. Ethanol from SS

\footnotetext{
Abbreviations: BESS, Biofuel Energy Systems Simulator; $\mathrm{CO}_{2} \mathrm{e}$, carbon dioxide equivalent of greenhouse gases including carbon dioxide, methane, and nitrous oxide; GHG, greenhouse gas; HPAL, High Plains Agricultural Laboratory; NCTA, Nebraska College of Technical Agriculture; SCAL, South Central Agricultural Laboratory; SOC, soil organic carbon; SS, sweet sorghum; WCREC, West Central Research and Extension Center.
} 
Table I. Soil and agronomic information for sweet sorghum research at seven Nebraska site-years.

\begin{tabular}{|c|c|c|c|c|c|c|c|}
\hline Site, soil, practice & HPAL07† & WCREC07 & SCAL07 & HPAL08 & NCTA08 & SCAL08 & Havelock08 \\
\hline Location and elevation & $\begin{array}{l}41^{\circ} 13^{\prime} \mathrm{N} \\
103^{\circ} 0^{\prime} \mathrm{W} \\
1316 \mathrm{~m}\end{array}$ & $\begin{array}{c}41^{\circ} 02^{\prime} \mathrm{N} \\
100^{\circ} 45^{\prime} \mathrm{W} \\
919 \mathrm{~m}\end{array}$ & $\begin{array}{c}40^{\circ} 34^{\prime} \mathrm{N} \\
98^{\circ} 07^{\prime} \mathrm{W} \\
550 \mathrm{~m}\end{array}$ & $\begin{array}{l}41^{\circ} 14^{\prime} \mathrm{N} \\
103^{\circ} 0^{\prime} \mathrm{W} \\
1292 \mathrm{~m}\end{array}$ & $\begin{array}{c}40^{\circ} 39^{\prime} \mathrm{N} \\
100^{\circ} 31^{\prime} \mathrm{W} \\
824 \mathrm{~m}\end{array}$ & $\begin{array}{c}40^{\circ} 34^{\prime} \mathrm{N} \\
98^{\circ} 08^{\prime} \mathrm{W} \\
552 \mathrm{~m}\end{array}$ & $\begin{array}{l}40^{\circ} 51^{\prime} \mathrm{N} \\
96^{\circ} 37^{\prime} \mathrm{W} \\
357 \mathrm{~m}\end{array}$ \\
\hline Soil series and slope & $\begin{array}{c}\text { Alliance silt loam, } \\
0-1 \%\end{array}$ & $\begin{array}{l}\text { Hall silt loam, } \\
0-1 \%\end{array}$ & $\begin{array}{c}\text { Crete silt loam, } \\
0-1 \%\end{array}$ & Keith loam, 0-I\% & $\begin{array}{c}\text { Hall silt loam, } \\
0-1 \%\end{array}$ & $\begin{array}{l}\text { Hastings silt } \\
\text { loam, } 0-1 \%\end{array}$ & $\begin{array}{c}\text { Aksarben silty } \\
\text { clay loam, 2-6\% }\end{array}$ \\
\hline Taxonomic class & $\begin{array}{l}\text { fine-silty, mixed, } \\
\text { mesic Aridic } \\
\text { Argiustolls }\end{array}$ & $\begin{array}{l}\text { fne-silty, mixed, } \\
\text { superactive, } \\
\text { mesic Pachic } \\
\text { Argiustolls }\end{array}$ & $\begin{array}{l}\text { fine, smectitic, } \\
\text { superactive, } \\
\text { mesic Pachic } \\
\text { Argiustolls }\end{array}$ & $\begin{array}{l}\text { fine-silty, mixed, } \\
\text { mesic Aridic } \\
\text { Argiustolls }\end{array}$ & $\begin{array}{l}\text { fine-silty, mixed, } \\
\text { mesic Pachic } \\
\text { Argiustolls }\end{array}$ & $\begin{array}{l}\text { fine, smectitic, } \\
\text { superactive, } \\
\text { mesic Udic } \\
\text { Argiustolls }\end{array}$ & $\begin{array}{c}\text { fine, smectitic, } \\
\text { mesic Typic } \\
\text { Argiudolls }\end{array}$ \\
\hline Previous crop & wheat & wheat & wheat & wheat & wheat & soybean & soybean \\
\hline \multicolumn{8}{|l|}{ Planting date } \\
\hline Corn & 12 May & 16 May & 22 May & 15 May & 9 May & 2 May & 13 May \\
\hline Grain sorghum & 6 June & 6 June & 29 May & 3I May & 3 June & I June & 13 May \\
\hline Sweet sorghum & 8 June & 6 June & 29 May & 3I May & 3 June & I5 May & 13 May \\
\hline Harvest date $\ddagger$ & 2 Oct. & I Oct. & 4 Sept. & 21 Oct. & Oct. $\neq$ & 29 Oct. $\ddagger$ & 8 Oct. $\ddagger$ \\
\hline Soil $\mathrm{pH}_{1: 1}$ & 6.55 & 5.45 & 5.66 & 5.61 & 6.04 & 7.03 & 4.62 \\
\hline SOM, $\mathrm{kg} \mathrm{kg}^{-1} \S$ & 20.9 & 18.0 & 27.6 & 17.7 & 24.2 & 26.0 & 36.6 \\
\hline Bray-I P, mg kg-1 & 17.2 & 71.3 & 32.6 & 7.7 & 18.3 & 11.5 & 13.4 \\
\hline Soil K, $\mathrm{mg} \mathrm{kg}^{-1}$ & 3250 & 668 & 529 & 741 & 331 & 385 & 479 \\
\hline Soil $\mathrm{NO}_{3}-\mathrm{N}, \mathrm{mg} \mathrm{kg}^{-1}$ & 5.98 & 7.59 & 3.68 & 7.28 & 14.56 & 6.49 & 3.33 \\
\hline
\end{tabular}

† HPAL, High Plains Agricultural Laboratory; NCTA, Nebraska College of Technical Agriculture; SCAL, South Central Agricultural Laboratory; WCREC, West Central Research and Extension Center; 07 and 08, 2007 and 2008.

‡ Harvest at NCTA in 2008 spanned several days because of wet weather. Sweet sorghum 'Simon' was harvested 6 Sept., 27 Aug., and 25 Aug. at NCTA, SCAL, and Havelock, respectively, in 2008.

§ SOM, soil organic matter. Soil properties were from the 0 - to $20-\mathrm{cm}$ depth, except $\mathrm{NO}_{3}-\mathrm{N}$ which was from the 0 - to $120-\mathrm{cm}$ depth.

would likely be in this category. Bioenergy yield and energy invested in producing the crop and converting it to ethanol are important factors in determining associated life cycle GHG emissions (Liska et al., 2009) as well as net energy yield (energy yield relative to energy invested). Low $\mathrm{N}$ rate requirements compared with grain crops and avoiding the need to convert starch to sugar favor SS relative to grain crops for more efficient ethanol production. To compare the ethanol-equivalent yield, $\mathrm{CO}_{2}$-equivalent $\left(\mathrm{CO}_{2} \mathrm{e}\right)$ emissions, and energy balance of crop-based ethanol production systems, the Biofuel Energy Systems Simulator (BESS model; Liska et al., 2009; available at www.bess.unl.edu; verified 3 Dec. 2009) provides a platform for analysis.

The objectives of this research were to compare the yield and efficiency of ethanol production from SS compared with corn or grain sorghum across a range of dryland environments and to develop $\mathrm{N}$ management and planting guidelines for SS production in Nebraska. These field results were used to estimate the direct life cycle GHG emissions associated with ethanol production from SS and the two grain crops (Liska et al., 2009).

\section{MATERIALS AND METHODS}

Research was conducted at seven site-years in Nebraska in 2007-2008 between $40^{\circ} 30^{\prime} \mathrm{N}$ to $41^{\circ} 15^{\prime} \mathrm{N}$ latitude and 350 to $1320 \mathrm{~m}$ elevation (Table 1). The soils were deep silt loam, loam, or silty clay loam. The previous crop was either soybean or winter wheat. All sites were no-till. A soil sample was taken for each block from the 0 - to $20-\mathrm{cm}$ depth before planting for basic analysis, and from the 0 - to $120-\mathrm{cm}$ depth for $\mathrm{NO}_{3}-\mathrm{N}$ analysis. Fertilizer $\mathrm{P}$ was broadcast applied without incorporation as triple superphosphate per University of Nebraska-Lincoln recommendations (Ferguson, 2000). Growing season rainfall and minimum and maximum temperature were recorded within 2 $\mathrm{km}$ of each site (Table 2).

\section{Treatments, Experimental Design, and Procedures}

The SS trials consisted of a randomized complete block design with a split-strip plot arrangement of treatments consisting of $\mathrm{N}$ rate, plant population, and cultivar. The $\mathrm{N}$ rates were 0,45 , and $90 \mathrm{~kg} \mathrm{ha}^{-1}$ surface applied before planting with urease inhibitor treated [ $\mathrm{N}$-(n-butyl) thiophosphoric triamide; Agrotain International, LCC, St. Louis, MO] urea. The plant population treatments were $75,000,125,000$, and 175,000 viable seed ha ${ }^{-1}$. The $\mathrm{N}$ rate and plant population treatments were applied in eight-row main plots that were split in a nonrandom manner into four-row subplots for the two cultivars, resulting in a split-strip plot arrangement of treatments. The SS cultivars were Keller and M81E in 2007, and Simon and M81E in 2008; Keller lodged badly at two locations in 2007 and was replaced with Simon in 2008. These cultivars were selected based on performance in eastern Nebraska cultivar trials. Only Simon was planted at the Nebraska College of Technical Agriculture (NCTA) in 2008 because the M81E seed was lost.

The row spacing for the eight-row main plots was $76 \mathrm{~cm}$. Plot length was $12 \mathrm{~m}$. There were four replications for each treatment. To the outside of each SS replication, main plots of corn and grain sorghum were planted for comparison of SS with grain crops. The main plots of corn and grain sorghum were split to have either no $\mathrm{N}$ applied or $\mathrm{N}$ applied at the recommended rate, which ranged from 67 to $112 \mathrm{~kg} \mathrm{ha}^{-1}$ dependent on crop, yield goal, and predicted soil $\mathrm{N}$ availability (Ferguson, 2000). The main plots of corn and grain sorghum were eight rows wide with $76-\mathrm{cm}$ spacing, $24 \mathrm{~m}$ long, and were split into $12 \mathrm{~m}$ subplots for $\mathrm{N}$ rates. The crop species were separated by at least four rows or $3 \mathrm{~m}$ of each crop to minimize border effects. 
Table 2. Monthly rainfall and mean minimum and maximum temperature for seven Nebraska site-years in 2007 and 2008.

\begin{tabular}{|c|c|c|c|c|c|c|c|c|c|c|c|c|c|c|c|}
\hline \multirow[b]{2}{*}{ Site-year $†$} & \multicolumn{3}{|c|}{ May } & \multicolumn{3}{|c|}{ Jun } & \multicolumn{3}{|c|}{ Jul } & \multicolumn{3}{|c|}{ Aug } & \multicolumn{3}{|c|}{ Sep } \\
\hline & Rain & Min & Max & Rain & Min & Max & Rain & Min & Max & Rain & Min & Max & Rain & Min & Max \\
\hline & $\mathrm{mm}$ & \multicolumn{2}{|c|}{${ }^{\circ} \mathrm{C}$} & $\mathrm{mm}$ & \multicolumn{2}{|c|}{${ }^{\circ} \mathrm{C}$} & $\mathrm{mm}$ & \multicolumn{2}{|c|}{${ }^{\circ} \mathrm{C}$} & $\mathrm{mm}$ & \multicolumn{2}{|c|}{${ }^{\circ} \mathrm{C}$} & $\mathrm{mm}$ & \multicolumn{2}{|c|}{${ }^{\circ} \mathrm{C}$} \\
\hline HPAL07 & 75 & 6.6 & 21.8 & 50 & 10.8 & 27.8 & 52 & 15.9 & 32.1 & 44 & 15.3 & 32.4 & 24 & 8.9 & 26.2 \\
\hline WCREC07 & 132 & 8.8 & 23.1 & 65 & 13.4 & 27.1 & 94 & 17.2 & 30.8 & 22 & 17.2 & 31.6 & 52 & 10.2 & 26.8 \\
\hline SCAL07 & 116 & II.I & 23.6 & 45 & 14.4 & 27.3 & 98 & 17.7 & 30.2 & 98 & 18.5 & 30.8 & 57 & 10.8 & 25.8 \\
\hline HPAL08 & 66 & 3.8 & 19.7 & 76 & 9.3 & 26.5 & 72 & 14.2 & 32.8 & 43 & 13.5 & 28.4 & 56 & 6.8 & 24.1 \\
\hline NCTA08 & 277 & 7.0 & 20.9 & 164 & 12.6 & 26.9 & 35 & 17.1 & 31.6 & 49 & 15.3 & 28.2 & 30 & 9.0 & 25.0 \\
\hline SCAL08 & 156 & 8.1 & 21.3 & 85 & $14 . \mid$ & 28.2 & 80 & 15.8 & 30.6 & 10 & 12.9 & 28.1 & 42 & 10.1 & 24.1 \\
\hline Havelock08 & 125 & 9.2 & 21.9 & 207 & 15.9 & 28.4 & 94 & 19.1 & 31.3 & 38 & 15.9 & 29.9 & 99 & 11.8 & 24.7 \\
\hline
\end{tabular}

† HPAL, High Plains Agricultural Laboratory; NCTA, Nebraska College of Technical Agriculture; SCAL, South Central Agricultural Laboratory; WCREC, West Central Research and Extension Center; 07 and 08, 2007 and 2008.

Grain yield of grain sorghum at the Havelock Agronomy Farm was not determined because of severe bird damage.

Sweet sorghum harvest consisted of cutting the stalks at 8 to $10 \mathrm{~cm}$ above the soil surface in a single, 3 -m length of row and counting harvested stalks. Harvest occurred at the soft dough stage for the earlier-maturing Simon, but was only near halfbloom or later stage and shortly before or after a killing frost for the later-maturity M81E and Keller (Table 1). Sweet sorghum biomass harvest was done in early September 2007 at South Central Agricultural Laboratory (SCAL07) when the crop was in the boot to half bloom growth stage because of severe lodging caused by strong winds, but Brix was measured later from standing plants at approximately the half bloom stage.

Fresh biomass weight was obtained at harvest. Leaves and panicles were removed from six stalks per treatment in one block. These six stalks were weighed with and without leaves and panicles to determine the mean conversion factor for converting all fresh biomass weights to fresh stalk weight. Brix is a measure of dissolved sugar to water mass ratio of a liquid. Brix was determined for six stalk segments per plot, with segments taken along the length of the stalks. Ten to 12 stalk segments of approximately 20 -cm length, with leaves, were cut from stalks randomly selected from the biomass samples and at different positions to obtain samples representative of stalk length. These samples were weighed wet, oven-dried, and weighed dry to determine the water content after correcting for leaf weight. Juice and sugar yield were calculated in three steps:

$$
\begin{aligned}
& C S Y=(F S Y-D S Y) \times \text { Brix } \times 0.75 \\
& J Y, 80 \% \text { extracted }=[F S Y-(D S Y-C S Y)] \times 0.8 \\
& S Y=J Y \times \text { Brix } \times 0.75
\end{aligned}
$$

where CSY is conservative sugar yield $\left(\mathrm{Mg} \mathrm{ha}^{-1}\right)$, FSY is fresh stalk yield $\left(\mathrm{Mg} \mathrm{ha}^{-1}\right)$, DSY is dry stalk yield $\left(\mathrm{Mg} \mathrm{ha}^{-1}\right)$, JY is juice yield $\left(\mathrm{Mg} \mathrm{ha}^{-1}\right)$, and SY is sugar yield $\left(\mathrm{Mg} \mathrm{ha}^{-1}\right)$. Sugar concentration of juice is $75 \%$ of Brix expressed in $\mathrm{g} \mathrm{kg}^{-1}$ sugar juice.

Corn and grain sorghum yield were determined by either ear or panicle harvest, respectively, from two rows $6 \mathrm{~m}$ in length. Subsamples of six ears or panicles were weighed and the shelling or threshing percentage determined. Grain water content was corrected to $155 \mathrm{~g} \mathrm{~kg}^{-1}$.

The ANOVAs for SS agronomic data by site-year were conducted using Statistix 9 (Analytical Software, Tallahassee, FL).
The ANOVA for the comparison of SS with corn and grain sorghum was combined across site-years for 2007, but was done by site-year for 2008 due to missing crop data at NCTA and Havelock. Site-year and replication effects were considered random and all treatment effects were considered fixed. Differences were considered significant at $P \leq 0.05$.

\section{Estimation of Ethanol-Equivalent Yield, Greenhouse Gas Emissions, and Energy Balance}

The BESS model (Liska et al., 2009) was used to calculate ethanol-equivalent yield, $\mathrm{CO}_{2}$ e emissions, and energy balance using state-of-the-art crop production and processing technology. The parameters and conversion efficiencies used in BESS are well documented in Liska et al. (2009) and most are not repeated in this paper. Emissions of $\mathrm{N}_{2} \mathrm{O}$ were determined based on the 2006 IPCC Guidelines for National Greenhouse Gas Inventories from the Intergovernmental Panel on Climate Change (available at http://www.ipcc-nggip.iges.or.jp/ public/2006gl/index.html; verified 3 Dec. 2009); BESS model equations were modified to account for $\mathrm{N}_{2} \mathrm{O}$ emission for SS crop residues. Emission of $\mathrm{N}_{2} \mathrm{O}$ from bagasse, stover, and roots was estimated as $1 \%$ of the $\mathrm{N}$ content, with $\mathrm{N}$ concentrations of 6 and $7 \mathrm{~g} \mathrm{~kg}^{-1}$ for above- and belowground biomass, respectively, and with root biomass equal to $25 \%$ of aboveground biomass. Ethanol yields from grain and fermentable sugar were based on industry survey data and theoretical yields, respectively (Table 3). Fermentable sugar yield of SS was estimated as $75 \%$ of the Brix value, with $80 \%$ of the sugar extracted from stalks and $95 \%$ of the extracted sugar converted to ethanol.

The BESS calculations were made assuming no-till production. Fuel use varied according to the crop and yield level (Table 3). Nitrogen rate used in the calculations varied according to recommendations for corn (Ferguson et al., 2000) and grain sorghum (Wortmann et al., 2006), while no $\mathrm{N}$ application was considered for SS production since SS yield was increased by $\mathrm{N}$ application in only one of seven site-years. Fertilizer $\mathrm{P}$ and $\mathrm{K}$ were applied at estimated removal rates for the grain crops, but calculations were done with no $\mathrm{P}$ and $\mathrm{K}$ application for SS, assuming that these nutrients would be returned to the fields in the bagasse. Application of $5 \mathrm{~kg} \mathrm{ha}^{-1}$ of herbicide and no other pesticide was assumed for all crops. Wet distillers grains fed to beef cattle were given an energy and GHG coproduct credit that was attributed to corn and grain sorghum in the offset of other energy-intensive feeds. It was assumed that corn and grain sorghum stover stayed in the field and SS bagasse was returned to the field with no energy 
Table 3. Parameter values used for estimation of ethanol yields, GHG emissions, and energy balances of corn, grain sorghum, and sweet sorghum in Nebraska.

\begin{tabular}{lcc}
\multicolumn{1}{c}{ Parametert } & Unit & Value \\
\hline $\begin{array}{l}\text { Crop production and harvest, diesel } \\
\text { No-till production }\end{array}$ & $\mathrm{L} \mathrm{ha}^{-1}$ & 4 \\
Grain harvest, $<8(>8) \mathrm{Mg} \mathrm{ha}^{-1}$ & $\mathrm{~L} \mathrm{ha}^{-1}$ & $9(\mathrm{I} 3)$ \\
SS harvest and crushing & $\mathrm{L} \mathrm{Mg}^{-1}$ fresh stalks $^{-}$ & 0.3 \\
Sugar-to-ethanol yield & & \\
Brix to fermentable sugar concentration & $\%$ & 75 \\
Stalk juice expressed & $\%$ & 80 \\
Fermentable sugar converted to alcohol & $\%$ & 95 \\
Biorefinery yields and energy inputs & & \\
Grain-to-ethanol conversion & $\mathrm{L} \mathrm{Mg}^{-1}$ & 423 \\
Sugar-to-ethanol conversion & $\mathrm{L} \mathrm{Mg}^{-1}$ & 665 \\
Grain ethanol natural gas input & $\mathrm{MJ} \mathrm{L}^{-1}$ ethanol & 5.44 \\
SS juice fermentation and distillation & $\mathrm{MJ} \mathrm{L}^{-1}$ ethanol & 3.33 \\
\hline
\end{tabular}

† All parameter values not shown above are reported in the BESS2008.3.I User's Guide (www.bess.unl.edu; verified 2 Dec. 2009) developed from analysis of the corn-ethanol life cycle (Liska et al., 2009).

‡Natural gas biorefinery in Nebraska producing wet distillers grains (BESS model default No. 5). The only cropping inputs for SS production besides fossil fuels were herbicide $\left(5 \mathrm{~kg} \mathrm{ha}^{-1}\right)$ and seed $\left(2 \mathrm{~kg} \mathrm{ha}^{-1}\right)$. Grain and SS juice transportation costs were assumed equivalent because of comparatively localized SS processing of higher masses. Biorefinery electricity use rate was assumed the same for all systems.

value given and no change in soil organic carbon (SOC). It was assumed that fuel consumed for transport of SS juice was similar to consumption for grain transport with shorter mean transport distance compensating for the greater SS mass transported. It was assumed that energy required for heating the juice for fermentation and distillation for SS was $3.3 \mathrm{MJ} \mathrm{L}^{-1}$ of ethanol for mean outdoor air temperature $<10^{\circ} \mathrm{C}$ during these processes (Table 3).

\section{RESULTS AND DISCUSSION}

Overall measured or estimated SS means were 15.2 stalks $\mathrm{m}^{-2}$ harvested, $109 \mathrm{~g} \mathrm{~g}^{-1}$ fermentable sugar concentration in juice assuming fermentable sugar equal to $0.75 \mathrm{Brix}, 51.4 \mathrm{Mg}$ $\mathrm{ha}^{-1}$ fresh stalk yield, $27.3 \mathrm{Mg} \mathrm{ha}^{-1}$ juice yield assuming $80 \%$ extraction efficiency, $3.38 \mathrm{Mg} \mathrm{ha}^{-1}$ fermentable sugar yield, and $2248 \mathrm{~L} \mathrm{ha}^{-1}$ ethanol yield assuming $95 \%$ of fermentable sugar is converted to ethanol (Table 4). Mean grain and calculated ethanol yield, respectively, were $7.94 \mathrm{Mg} \mathrm{ha}^{-1}$ and $3361 \mathrm{~L} \mathrm{ha}^{-1}$ for corn, and $6.16 \mathrm{Mg} \mathrm{ha}^{-1}$ and $2612 \mathrm{~L} \mathrm{ha}^{-1}$ for grain sorghum (Table 5).

\section{Effects of Plant Population, Nitrogen Rate, and Cultivar}

Variables of SS were not affected by two- and three-way interactions of $\mathrm{N}$ rate, plant population, and SS cultivars. Plant population effects on SS variables were not significant except for effects on stalk $\mathrm{m}^{-2}$ at five site-years and juice, sugar, and ethanol yield at NCTA (Table 4). Stalk $\mathrm{m}^{-2}$ increased by 32 to $43 \%$, with increased plant population at High Plains Agricultural Laboratory (HPAL) and West Central Research and Extension Center (WCREC) in 2007 and at SCAL, NCTA, and Havelock in 2008. Yields of fresh stalks, juice, sugar, and ethanol were 14 to $19 \%$ greater at NCTA in 2008, with 17.5 seed $\mathrm{m}^{-2}$ compared with the lower seed rates. Fresh stalk yield was decreased but Brix was increased with the high seeding rate compared with the lower rates at Havelock in 2008. The general lack of plant population effect on sugar yield is consistent with Lueschen et al. (1991) and Ferraris and Charles-Edwards
(1986), who reported no plant population effects on SS yield and sugar concentration.

Sweet sorghum was not affected by $\mathrm{N}$ rate at four of seven site-years (Table 4). Sugar concentration (Brix) increased by 5\% at HPAL in 2007 but decreased by $5 \%$ at NCTA and by $7 \%$ at SCAL in 2008 with increased $\mathrm{N}$ rate. Fresh biomass, juice, sugar, and ethanol yield increased 19 to $27 \%$ with increasing $\mathrm{N}$ rate at NCTA in 2008, the site-years where sugar yield was greatest compared with other site-years. This occurred even though preplant soil nitrate $\mathrm{N}$ at this site-year (Table 1) was high compared with most site-years. Brix was $3 \%$ higher with 40 compared with $80 \mathrm{~kg} \mathrm{~N} \mathrm{ha}^{-1}$ applied at SCAL in 2008. Corn and grain sorghum yield were increased by means of 19 and $10 \%$, respectively, with $\mathrm{N}$ application (data not reported). While substantial SS yield increase occurred with $\mathrm{N}$ application in Louisiana (Ricaud and Arenneaux, 1990), lack of SS response to applied $\mathrm{N}$ is common (Wiendenfeld, 1984; Lueschen et al., 1991; Barbanti et al., 2006). Based on other data collected by the authors of this paper (unpublished data, 2008), this lack of greater response of SS to $\mathrm{N}$ application is attributed to less $\mathrm{N}$ uptake, a more gradual rate of nutrient uptake, and $\mathrm{N}$ uptake later in the season compared with the grain crops.

An unmeasured observation was that Keller was the cultivar most susceptible to lodging with severe damage observed at SCAL and WCREC in 2007, while M81E was only moderately susceptible. Simon was earlier to mature and reached dough stage by early September, while most stalks of M81E and Keller were in preanthesis to milk growth stages by October. The performance of the SS cultivars Keller and Simon, relative to M81E, was inconsistent across site-years for sugar content and yield (Table 4). Because of later maturity, Keller and M81E were harvested before the soft dough stage of grainfill was reached, the stage when sugar concentration is expected to peak (Broadhead, 1973; Broadhead, 1974; Tarpley et al., 1994).

\section{Ethanol-Equivalent Yield, Greenhouse Gas Emissions, and Energy Balance}

Corn grain yield $\left(\mathrm{Y}_{\mathrm{C}}\right)$ ranged from 4.6 to $11.8 \mathrm{Mg} \mathrm{ha}^{-1}$ with a mean of $8.4 \mathrm{Mg} \mathrm{ha}^{-1}$. Grain sorghum grain yield $\left(\mathrm{Y}_{\mathrm{GS}}\right)$ ranged from 4.2 to $9.2 \mathrm{Mg} \mathrm{ha}^{-1}$, with a mean of $6.2 \mathrm{Mg} \mathrm{ha}^{-1}$ and was related to $\mathrm{Y}_{\mathrm{C}}$ as $\mathrm{Y}_{\mathrm{GS}}=0.67 \mathrm{Y}_{\mathrm{C}}+0.70\left(R^{2}=0.81\right)$. Staggenborg et al. (2008) reported corn to have a grain yield advantage compared with grain sorghum under water-deficit conditions when corn grain yields exceed $6.4 \mathrm{Mg} \mathrm{ha}^{-1}$. Estimated ethanol yield of SS varied across site-years independently of corn and grain sorghum grain yield (Fig. 1). Mean ethanol yield was $52 \%$ more with corn and $18 \%$ more with grain sorghum compared with SS (Table 5). Planting of all crops, especially grain sorghum and SS, was often later than intended due to weather conditions and competing priorities. The yields of the sorghum crops may have been higher with earlier planting, although the planting dates were not late compared with farmers' practice.

Calculated ethanol yield for SS was less than the yield for the two grain crops at all site-years, with the exception of NCTA in 2008. Ethanol yield with the three crops was less at HPAL, where in-season rainfall was $<350 \mathrm{~mm}$ and elevation was higher, which causes a shorter growing season, compared with the other site-years. Ethanol yield for the three crops, however, 
Table 4. Plant population, $\mathbf{N}$ rate, and cultivar effects on seven sweet sorghum properties at seven Nebraska site-years.

\begin{tabular}{|c|c|c|c|c|c|c|c|}
\hline Site-year† & Stalks & $\begin{array}{l}\text { Fresh stalk } \\
\text { yield }\end{array}$ & $\begin{array}{l}\text { Dry stalk } \\
\text { yield }\end{array}$ & $\begin{array}{l}\text { Juice yield, } \\
80 \% \text { expressed }\end{array}$ & $\begin{array}{l}\text { Sugar content, } \\
\mathbf{7 5 \%} \text { Brix }\end{array}$ & $\begin{array}{c}\text { Sugar } \\
\text { yield }\end{array}$ & $\begin{array}{l}\text { Ethanol } \\
\text { yield }\end{array}$ \\
\hline & $\mathrm{m}^{-2}$ & 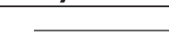 & $-\mathrm{Mg} \mathrm{ha}^{-\mathrm{I}}$ & & $\mathrm{g} \mathrm{kg}^{-1}$ & $\mathrm{Mg} \mathrm{ha}^{-1}$ & $\mathrm{~L} \mathrm{ha}^{-1}$ \\
\hline \multicolumn{8}{|l|}{ HPAL07 } \\
\hline Population & $* * *$ & NS $\ddagger$ & NS & NS & NS & NS & NS \\
\hline $\mathrm{N}$ rate & $*$ & NS & NS & NS & * & NS & NS \\
\hline Keller & $13.4 \mathrm{~b} \ddagger$ & $34.24 \mathrm{~b} \S$ & 11.99 & $19.84 \mathrm{a}$ & $114.4 \mathrm{a}$ & 2.27 & 1509 \\
\hline M8IE & $14.8 \mathrm{a}$ & $38.00 \mathrm{a}$ & $12.5 \mid$ & $22.37 \mathrm{~b}$ & $96.9 b$ & 2.17 & $|44|$ \\
\hline \multicolumn{8}{|l|}{ HPAL08 } \\
\hline Population & NS & NS & NS & NS & NS & NS & NS \\
\hline $\mathrm{N}$ rate & NS & NS & NS & NS & NS & NS & NS \\
\hline M8IE & 12.7 & 27.57 & $7.5 \mathrm{lb}$ & 17.39 & $83.6 \mathrm{~b}$ & $1.45 \mathrm{a}$ & $967 a$ \\
\hline Simon & 12.3 & 27.32 & $8.43 a$ & 17.14 & $133.9 \mathrm{a}$ & $2.29 b$ & $1526 \mathrm{~b}$ \\
\hline \multicolumn{8}{|l|}{ WCREC07 } \\
\hline Population & $* * *$ & NS & NS & NS & NS & NS & NS \\
\hline $\mathrm{N}$ rate & NA & NS & NS & NS & NS & NS & NS \\
\hline Keller & $24.9 \mathrm{a}$ & $59.45 b$ & 22.57 & $32.52 \mathrm{a}$ & $102.3 \mathrm{a}$ & 3.33 & 2212 \\
\hline M8IE & $17.8 \mathrm{~b}$ & $69.91 \mathrm{a}$ & 23.36 & $40.36 \mathrm{~b}$ & $83.8 \mathrm{~b}$ & 3.38 & 2249 \\
\hline \multicolumn{8}{|l|}{ NCTA08,'Simon’ } \\
\hline 7.5 seed $\mathrm{m}^{-2}$ & 14.1 & $92.98 \mathrm{~b}$ & 45.03 & $43.07 \mathrm{a}$ & 122.3 & $5.27 \mathrm{a}$ & $3503 a$ \\
\hline 12.5 seed $\mathrm{m}^{-2}$ & 16.3 & $91.55 \mathrm{~b}$ & 42.34 & $44.05 a$ & 119.0 & $5.24 \mathrm{a}$ & $3486 a$ \\
\hline 17.5 seed $\mathrm{m}^{-2}$ & 18.9 & $104.78 \mathrm{a}$ & 46.47 & $52.20 \mathrm{~b}$ & 119.0 & $6.2 \mathrm{Ib}$ & $4|3| b$ \\
\hline Population & $* *$ & $*$ & NS & $*$ & NS & $*$ & $*$ \\
\hline $\mathrm{N}, 0 \mathrm{~kg} \mathrm{ha}^{-1}$ & 15.5 & $86.32 b$ & 40.14 & $41.54 a$ & $124.3 \mathrm{a}$ & $5.16 a$ & $3433 a$ \\
\hline $\mathrm{N}, 40 \mathrm{~kg} \mathrm{ha}^{-1}$ & 17.1 & $96.58 \mathrm{~b}$ & 45.91 & $45.32 \mathrm{a}$ & $118.0 \mathrm{~b}$ & $5.35 a$ & $3556 a$ \\
\hline $\mathrm{N}, 80 \mathrm{~kg} \mathrm{ha}^{-1}$ & 16.8 & $106.42 a$ & 47.78 & $52.45 b$ & $118.1 \mathrm{~b}$ & $6.19 \mathrm{~b}$ & $4119 b$ \\
\hline \multicolumn{8}{|l|}{ SCAL07 } \\
\hline Population & NS & NS & NS & NS & NS & NS & NS \\
\hline $\mathrm{N}$ rate & NS & NS & NS & NS & NS & NS & NS \\
\hline Keller & $10.6 \mathrm{~b}$ & 47.95 & 15.30 & 29.07 & 112.90 & 3.28 & 2182 \\
\hline M8IE & $12.8 \mathrm{a}$ & 54.44 & 17.73 & 32.79 & 116.40 & 3.82 & 2538 \\
\hline \multicolumn{8}{|l|}{ SCAL08 } \\
\hline Population & $* *$ & NS & NS & NS & NS & NS & NS \\
\hline $\mathrm{N}$ rate & NS & NS & NS & NS & $*$ & NS & NS \\
\hline M8IE & $12.7 \mathrm{a}$ & 51.12 & $14.16 \mathrm{a}$ & $33.33 \mathrm{~b}$ & $119.5 b$ & $5.3 \mathrm{lb}$ & $3530 b$ \\
\hline Simon & $14.2 \mathrm{~b}$ & 50.95 & $18.08 \mathrm{~b}$ & $28.82 \mathrm{a}$ & $96.6 a$ & $3.7 \mathrm{Ia}$ & $2465 a$ \\
\hline \multicolumn{8}{|l|}{ Havelock08 } \\
\hline Population & $* * *$ & $* *$ & NS & NS & $*$ & NS & NS \\
\hline $\mathrm{N}$ rate & NS & NS & NS & NS & NS & NS & NS \\
\hline M8IE & 19.6 & $48.4 \mathrm{Ib}$ & $20.80 \mathrm{~b}$ & $24.53 a$ & $110.60 \mathrm{~b}$ & $2.7 \mathrm{Ia}$ & $1804 a$ \\
\hline Simon & 19.1 & $75.61 \mathrm{a}$ & $34.02 \mathrm{a}$ & $37.43 b$ & $124.90 \mathrm{a}$ & $4.67 \mathrm{~b}$ & $3109 b$ \\
\hline \multicolumn{8}{|c|}{ * Significant at the 0.05 probability level. } \\
\hline \multicolumn{8}{|c|}{ ** Significant at the 0.01 probability level. } \\
\hline \multicolumn{8}{|c|}{$* * *$ Significant at the 0.001 probability level. } \\
\hline \multicolumn{8}{|c|}{$\begin{array}{l}\text { † HPAL, High Plains Agricultural Laboratory; NCTA, Nebraska College of Technical Agriculture; SCAL, South Central Agricultural Laboratory; WCREC, West Centra } \\
\text { Research and Extension Center; } 07 \text { and 08, } 2007 \text { and } 2008 .\end{array}$} \\
\hline \multicolumn{8}{|c|}{$\ddagger N S$ refers to not significant at the 0.05 probability level. } \\
\hline
\end{tabular}

was not related to rainfall amount for site-years where in-season rainfall ranged from 430 to $660 \mathrm{~mm}$. Juice yield and Brix accounted for 83 and $15 \%$ of the variation in calculated ethanol yield of SS across site-years, respectively.

Calculated crop energy use was greatest for corn and least for SS (Table 5). Sweet sorghum had the highest estimates for transportation fuel consumption because of high harvest and juice extraction requirements (data not shown). Estimated total energy use $\left(\mathrm{MJ} \mathrm{L}^{-1}\right)$ was $41 \%$ more with corn and grain sorghum compared with SS. Net energy yield was $49 \%$ more with corn and $18 \%$ more with grain sorghum compared with SS cultivars Keller and M81E, but 12\% more with corn and $12 \%$ less with grain sorghum compared with SS cultivar Simon. Energy yield per energy invested was $9 \%$ more for the mean of the grain crops compared with SS.
Life cycle GHG emissions per liter of ethanol produced were 16 and $24 \%$ less for corn and grain sorghum, respectively, compared with SS, primarily due to higher $\mathrm{N}_{2} \mathrm{O}$ emissions from crop biomass left to decompose on the field (Table 5) and the lack of a SS coproduct credit (Table 6). Approximately $15 \%$ of the $\mathrm{CO}_{2}$ e emission associated with SS production was estimated to consist of $\mathrm{CO}_{2}$ emissions, while $85 \%$ of emissions were $\mathrm{N}_{2} \mathrm{O}$ from residue decomposition. Estimated emission of $\mathrm{CO}_{2}$ e per unit of ethanol produced associated with crop production were $9 \%$ less with corn and $31 \%$ less with grain sorghum compared with SS (Table 5). While $\mathrm{N}$ was not applied to SS, $60 \%$ of the $\mathrm{CO}_{2}$ e emission associated with corn production was $\mathrm{N}_{2} \mathrm{O}$ emission because of fertilizer $\mathrm{N}$ application and plant residue decomposition. Whereas life cycle GHG emissions for ethanol from grain crops averaged between 66 and 69\% less 
Table 5. Mean yields and calculated $\mathrm{CO}_{2}$ e emissions for grain and sugar produced $\left(\mathrm{kg} \mathrm{Mg}^{-1}\right)$, ethanol produced ( $\left.\mathrm{kg} \mathrm{Mg}^{-1}\right)$, and energy balances of corn, grain sorghum, and sweet sorghum ('M8IE', 'Keller', and 'Simon') at seven Nebraska site-years. Grain crops included a standard energy and GHG coproduct credit, while no coproduct was included for sweet sorghum.

\begin{tabular}{|c|c|c|c|c|c|c|c|c|}
\hline & \multicolumn{4}{|c|}{$2007, n=3$} & \multicolumn{4}{|c|}{$2008, n=4$} \\
\hline & \multirow[b]{2}{*}{ Corn } & \multirow{2}{*}{$\begin{array}{c}\text { Grain } \\
\text { sorghum }\end{array}$} & \multicolumn{2}{|c|}{ Sweet sorghum } & \multirow[b]{2}{*}{ Corn } & \multirow{2}{*}{$\begin{array}{c}\text { Grain } \\
\text { sorghum }\end{array}$} & \multicolumn{2}{|c|}{ Sweet sorghum } \\
\hline & & & M8IE & Keller & & & M8IE & Simon \\
\hline Grain or sugar yield, $\mathrm{Mg} \mathrm{ha}^{-1}$ & 7.36 & 5.73 & 3.12 & 2.96 & 8.38 & 6.62 & 3.16 & 4.06 \\
\hline $\mathrm{N}$ rate, $\mathrm{kg} \mathrm{ha}^{-1}$ & 97 & 48 & 0 & 0 & 115 & 52 & 0 & 0 \\
\hline Ethanol yield, $\mathrm{L} \mathrm{ha}^{-1}$ & 3113 & 2422 & 2077 & 1968 & 3547 & 2801 & 2099 & 2700 \\
\hline Crop† energy use $\mathrm{MJ} \mathrm{ha}{ }^{-1}$ & 8411 & 5594 & 3291 & 3282 & 9323 & 5939 & 3133 & 3466 \\
\hline Cropt $\mathrm{CO}_{2}$ emission, $\mathrm{kg} \mathrm{Mg}^{-1}$ & 78.7 & 68.3 & 78.2 & 79.8 & 76.6 & 63.7 & 89.3 & 65.0 \\
\hline Cropt $\mathrm{CH}_{4}$ emission, $\mathrm{kg} \mathrm{Mg}^{-1}$ & 0.08 & 0.07 & 0.06 & 0.06 & 0.08 & 0.07 & 0.07 & 0.05 \\
\hline Cropt $\mathrm{N}_{2} \mathrm{O}$ emission, $\mathrm{kg} \mathrm{Mg}^{-1}$ & 0.37 & 0.27 & 0.83 & 0.81 & 0.38 & 0.25 & 0.79 & 0.94 \\
\hline Cropt $\mathrm{CO}_{2} \mathrm{e} \ddagger$ emission, $\mathrm{kg} \mathrm{Mg}^{-1}$ & 191 & 149 & 328 & 323 & 192 & $|4|$ & 327 & 345 \\
\hline Cropt $\mathrm{CO}_{2} \mathrm{e}$ emission, $\mathrm{g} \mathrm{MJ}^{-1}$ & 21.4 & 16.7 & 23.4 & 23.0 & 21.5 & 15.8 & 23.3 & 24.6 \\
\hline Life cycle $\mathrm{CO}_{2}$ e emission, g $\mathrm{MJ}^{-1}$ & 31.1 & 28.7 & 41.9 & 40.4 & 31.2 & 28.2 & 41.8 & 43.1 \\
\hline Energy use rate, $\mathrm{MJ} \mathrm{L}^{-1}$ & 11.0 & 10.5 & 7.65 & 7.39 & 10.9 & 10.4 & 7.90 & 7.37 \\
\hline Energy yield, GJ ha ${ }^{-1}$ & 72.6 & 56.0 & 43.8 & 41.5 & 82.5 & 64.5 & 44.3 & 57.0 \\
\hline Energy consumed, GJ ha ${ }^{-1}$ & 34.1 & 25.5 & 15.7 & 14.6 & 38.5 & 29.0 & 15.7 & 19.6 \\
\hline Net energy yield, GJ ha ${ }^{-1}$ & 38.5 & 30.5 & 28.1 & 26.9 & 44.0 & 35.5 & 28.6 & 37.3 \\
\hline Net energy ratio & 2.13 & 2.20 & 2.76 & 2.86 & 2.13 & 2.22 & 2.70 & 2.87 \\
\hline $\mathrm{CO}_{2}$ e reduction, $\% \S$ & 66.1 & 68.8 & 52.9 & 54.5 & 66.1 & 69.4 & 53.0 & 51.6 \\
\hline
\end{tabular}

† Energy use and emissions associated with crop production. These and other estimates were calculated using the Biofuel Energy Systems Simulator (BESS; available at www.bess.unl.edu; confirmed 2 Dec. 2009)

$\ddagger \mathrm{CO}_{2} \mathrm{e}$, total global warming potential expressed as $\mathrm{CO}_{2}$ equivalent.

$\S \mathrm{CO}_{2} \mathrm{e}$ reduction associated with ethanol production and use compared with gasoline assuming $92 \mathrm{~g} \mathrm{CO}_{2} \mathrm{e}$ emission $\mathrm{MJ}^{-1}$ for gasoline.

than gasoline, ethanol from SS was found to reduce emissions by 52 to $54 \%$ on average (Table 5 , Fig. 2). The reduction in GHG emissions was more variable with SS compared with the
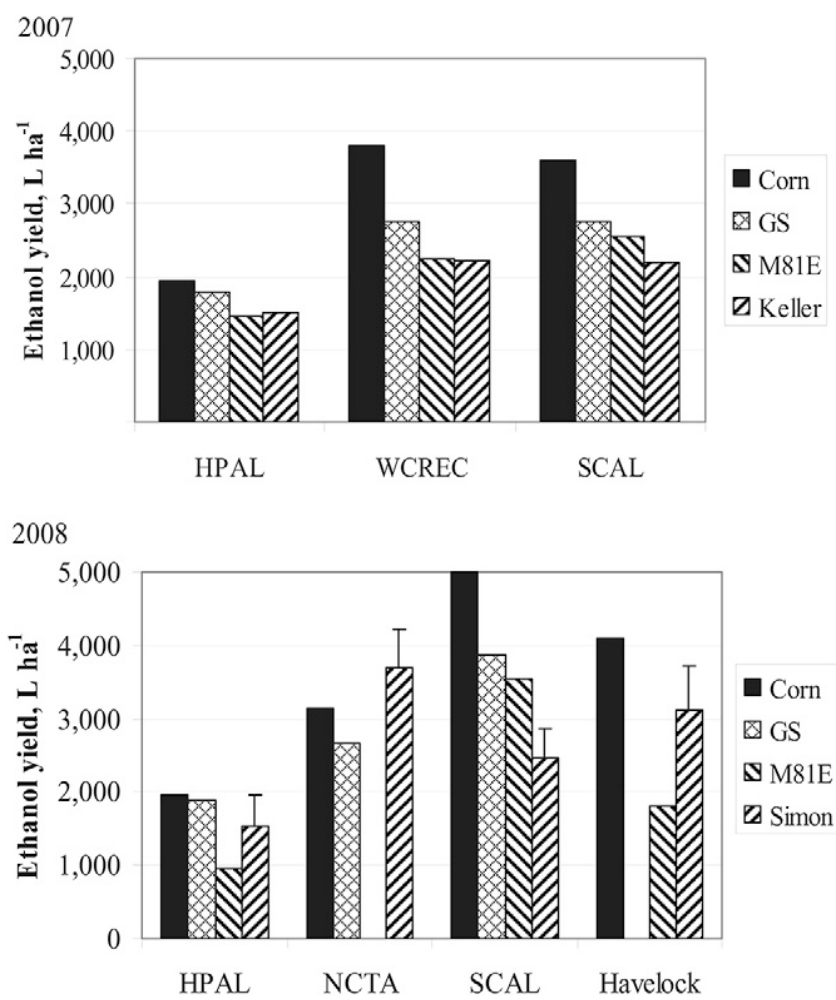

Fig. I. Calculated ethanol yield of corn, grain sorghum, and sweet sorghum at three sites in 2007 and four sites in 2008 in Nebraska. The ANOVA was combined for sites in 2007 and the LSD 0.05 was $507 \mathrm{~L} \mathrm{ha}^{-1}$. The 2008 sites were analyzed separately because of sites with a missing crop or cultivar; the Y-bars indicate the LSD 0.05 for each site. HPAL, High Plains Agricultural Laboratory; NCTA, Nebraska College of Technical Agriculture; SCAL, South Central Agricultural Laboratory; WCREC, West Central Research and Extension Center. grain crops; the coefficients of variation were 7 to $14 \%$ for SS, but $<3 \%$ for the grain crops.

These results show that SS will likely qualify as an advanced biofuel (per the Energy Independence and Security Act of 2007), with $>50 \%$ reduction in GHG emission compared with gasoline, under the Energy Independence and Security Act of 2007. Life cycle GHG assessment requirements administered by the USEPA, however, have not yet been formalized. These regulations could impose additional indirect emissions in the life cycle due to land use change, which could systematically shift the GHG emissions results downward for most biofuels (Liska and Perrin, 2009). Performing better than SS, the

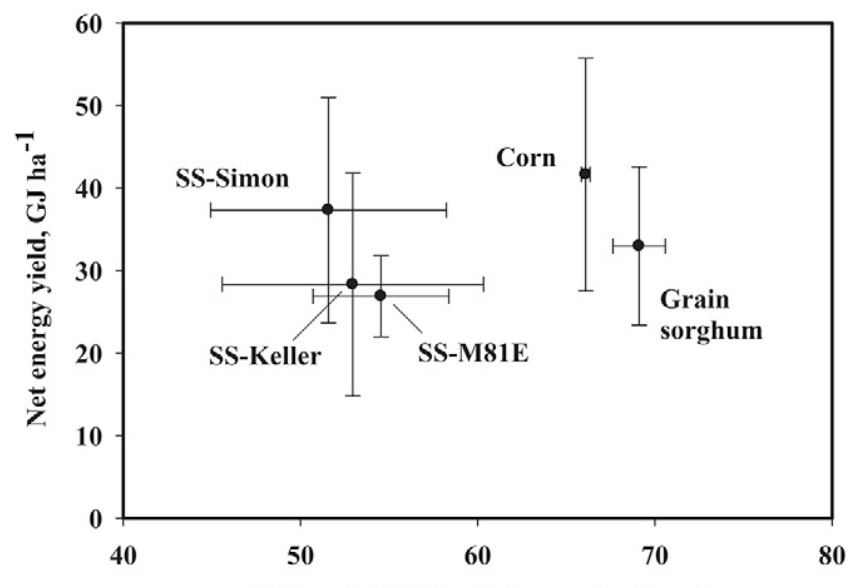

Life cycle GHG emissions reduction, \%

Fig. 2. Average life cycle net energy yield and reduction of greenhouse gas emissions compared with gasoline of ethanol produced from sweet sorghum and grain crops in a study conducted at seven site-years in Nebraska. Error bars indicate the standard deviation based on data from seven site-years. Calculations did not account for potential $\mathrm{N}_{2} \mathrm{O}$ emissions resulting from use of grain and grain coproducts, and assumed the most efficient grain biorefinery configuration. 
dryland corn-ethanol and grain sorghum-ethanol systems with efficient use of wet distillers grains described in this study are considered near the upper end of the performance efficiency for grain-based biofuel systems (Liska et al., 2009). Based on other studies, GHG emissions from SS are comparable with the average for corn-ethanol systems, including less efficient systems with less efficient use of coproducts compared with the system used in this study, which reduce GHG emissions by roughly $50 \%$ compared with gasoline.

If crop residues from SS are removed from the field, the anticipated declines in SOC will result in increased net $\mathrm{C}$ emissions. With complete residue removal, loss of SOC is estimated to be approximately $0.8 \mathrm{Mg} \mathrm{ha}^{-1} \mathrm{yr}^{-1}$ (AndersonTeixeira et al., 2009) which would be an additional emission of $63 \mathrm{~g} \mathrm{CO}_{2} \mathrm{e} \mathrm{MJ}^{-1}$ of ethanol. This would increase net life cycle emissions to $18 \%$ greater compared with gasoline, based on the average scenario (Table 6). This suggests that SS bagasse should be returned to the field to maintain SOC, despite causing substantial $\mathrm{N}_{2} \mathrm{O}$ emissions, unless either the feeding or a bioenergy use of bagasse results in sufficient life cycle reduction in $\mathrm{CO}_{2} \mathrm{e}$ emissions to compensate for loss of SOC.

The crop $\mathrm{N}_{2} \mathrm{O}$ emission estimates used in this study do not account for grain $\mathrm{N}$ that is eventually emitted as $\mathrm{N}_{2} \mathrm{O}$ during ethanol production and handling of the coproducts and the amount that would occur from excrement of animals fed the coproducts. The coproducts, used as a substitute for corn and protein sources, often make up 20 to $40 \%$ of beef cattle rations. The resulting rations have more protein than needed for efficient cattle growth. This results in more manure $\mathrm{N}$ excretion than occurs with traditional rations and likely causes more $\mathrm{N}_{2} \mathrm{O}$ emission during storage and handling, and following land application of manure compared with traditional beef cattle rations. There was no attempt, however, to estimate the $\mathrm{N}_{2} \mathrm{O}$ emission from grain $\mathrm{N}$ in this study, resulting in estimates of crop $\mathrm{N}_{2} \mathrm{O}$ emission that are likely low for the grain crops.

Estimated SS sugar yield and concentration in this study were low compared with concentrations reported by Vermerris et al. (2007) and Ricaud et al. (1979). Energy yield and energy balance would have been increased, and $\mathrm{CO}_{2} \mathrm{e}$ emission reduced, for SS harvested at a higher sugar concentration. The low sugar concentration observed in this study for Keller and M81E is attributed to the many SS stalks that had not produced a panicle and to the large number of panicles that had not reached the dough stage by harvest time. The SS cultivar Simon did reach the dough stage, and sugar yields may have been higher if SS harvest dates had been selected based on monitoring for peak sugar concentration. The low SS sugar content resulted in relatively low ethanol yield in $\mathrm{L} \mathrm{ha}^{-1}$ and $\mathrm{L} \mathrm{Mg}^{-1}$ of biomass. Energy use efficiency for SS in this study was also low compared with potentially higher SS sugar contents per the reasons stated above. The low SS concentrations resulted in more fuel and energy consumption for biomass harvest and juice extraction, transport, fermentation, and distillation per liter of ethanol produced. Emissions of $\mathrm{CO}_{2} \mathrm{e} \mathrm{L}^{-1}$ ethanol produced would decrease with increased sugar concentration.

When comparing SS to grain crops for ethanol production, the progress made in improving the efficiency of ethanol production from grain needs to be considered (Liska et al., 2009).
Table 6. Life cycle greenhouse gas emissions inventory of ethanol production from grain of corn and grain sorghum, and sweet sorghum ('M8IE') sugar for the WCREC, 2007 siteyears which had production levels near the seven Nebraska site-year average.

\begin{tabular}{|c|c|c|c|}
\hline GHG emission category & $\begin{array}{l}\text { Corn } \\
\text { grain }\end{array}$ & $\begin{array}{c}\text { Sorghum } \\
\text { grain }\end{array}$ & $\begin{array}{c}\text { Sweet } \\
\text { sorghum }\end{array}$ \\
\hline & \multicolumn{3}{|c|}{$-\mathrm{g} \mathrm{CO}_{2} \mathrm{e} \mathrm{MJ}^{-1}$ of ethanol produced +} \\
\hline \multicolumn{4}{|l|}{ Crop production } \\
\hline Nitrogen fertilizer & 4.12 & 2.27 & 0 \\
\hline Phosphorus fertilizer & 1.0 & 1.0 & 0 \\
\hline Potassium fertilizer & 0.596 & 0.604 & 0 \\
\hline Herbicides & 1.56 & 2.16 & 2.68 \\
\hline Seed & 0.40 & 0.097 & 0.034 \\
\hline Diesel & 0.753 & 0.797 & 2.66 \\
\hline Depreciable capital & 0.297 & 0.411 & 0.509 \\
\hline $\mathrm{N}_{2} \mathrm{O}$ emissions & 13.1 & 8.70 & 22.1 \\
\hline Total & 21.8 & 16.0 & 26.0 \\
\hline \multicolumn{4}{|l|}{ Biorefinery } \\
\hline Natural gas input & 15.4 & 15.4 & 9.43 \\
\hline Electricity input & 6.53 & 6.53 & 6.53 \\
\hline Depreciable capital & 0.458 & 0.458 & 0.458 \\
\hline Grain transportation & 2.11 & 2.11 & 2.11 \\
\hline Total & 24.5 & 24.5 & 18.5 \\
\hline \multicolumn{4}{|l|}{ Coproduct credit } \\
\hline Diesel & 0.301 & 0.301 & 0 \\
\hline Urea production & -2.69 & -2.69 & 0 \\
\hline Corn production & -10.3 & -7.56 & 0 \\
\hline Enteric fermentable.- $\mathrm{CH}_{4}$ & -3.69 & -3.69 & 0 \\
\hline Total & -16.4 & -13.6 & 0 \\
\hline Life-cycle net GHG emissions & 31.3 & 28.3 & 45.9 \\
\hline GHG reduction relative to gasoline, $\%$ & 65.9 & 69.2 & 50.1 \\
\hline
\end{tabular}

† $\mathrm{CO} 2$ e, total global warming potential expressed as $\mathrm{CO}_{2}$ equivalent.

Full credit was given in this study for the energy and GHG value of grain distillers coproducts. These coproducts are in much demand by beef cattle feeders because they are highly nutritious, result in improved growth rates, and provide feed use efficiency (Farran et al., 2006; Klopfenstein et al., 2008). Substituting distillers' coproducts for other feeds in beef rations is estimated to reduce $\mathrm{CO}_{2}$ e emissions by 28 to $30 \%$ in the corn-ethanol life cycles (Liska et al., 2009), assuming that feeding coproducts does not result in increased $\mathrm{N}_{2} \mathrm{O}$ emission from excreted $\mathrm{N}$. The grain-ethanol process benefits from the tremendous genetic and management gains that have occurred in Nebraska corn production. To a lesser extent, similar gains have occurred in grain sorghum production.

For the purposes of this study, an assumption was made that only $80 \%$ of the sugar was extracted from the stalks. More efficient extraction technology would increase ethanol yield and efficiency of SS. It was also assumed that fermentable sugars were $75 \%$ of the Brix reading; however, the concentration relative to Brix may be higher in many cases. Energy value as a fuel or animal feed might have been given to the SS bagasse, but it was assumed it would be land applied and was only credited for the return of the $\mathrm{P}$ and $\mathrm{K}$ although the $\mathrm{C}, \mathrm{N}$, and other nutrients that also would be returned to the land have energy value and contribute to reduced $\mathrm{CO}_{2}$ e emissions. Energy required for heating the juice for efficient fermentation and for distillation, which in this study was assumed to occur mostly in late fall, should be less with higher air temperatures and with the application of efficient heat exchange technology. Sweet sorghum productivity in Nebraska can probably be greatly improved through plant breeding; cultivars used in this 
study are relatively old and, although selected for performance from a wider set of cultivars, not particularly well-adapted to Nebraska conditions.

\section{CONCLUSION}

Sweet sorghum sugar yield was improved by increasing sowing rate above 75,000 viable seed $\mathrm{ha}^{-1}$ and with $\mathrm{N}$ application only at one of seven site-years, while corn and grain sorghum yields were increased by $\mathrm{N}$ application in most site-years. In consideration of unpublished data, the lack of more frequent response of SS to applied $\mathrm{N}$ is attributed to a lower rate of peak $\mathrm{N}$ uptake, proportionally more $\mathrm{N}$ uptake occurring later in the growing season, and to less total $\mathrm{N}$ uptake compared with corn and grain sorghum.

Mean calculated ethanol yield and net energy yield were less with SS than with the grain crops, but mean net energy yield of one of the SS cultivars evaluated, Simon, was comparable with the grain crops. The grain crops were much more efficient in terms of ethanol produced per petroleum invested as ethanol yields were higher and less fuel was used for grain crops compared with SS. Higher SS sugar concentrations would result in improved fuel use efficiency for harvest, crushing, and transport. Ethanol production with SS was more energy use efficient compared with the grain crops, with $25 \%$ more energy produced per MJ of energy invested.

The efficiency of SS might be improved by better use of bagasse that was assumed to be returned to the field in this study. The efficient use of the ethanol coproducts of corn and grain sorghum for feeding beef cattle as wet distillers grain, a common practice in Nebraska, contributed greatly to the efficiency of grain crops for ethanol production.

The later-maturing SS cultivars Keller and M81E both had $>50 \%$ of the stalks that did not reach the dough stage at any of the seven site-years. This resulted in sugar concentrations that were lower than what might have occurred with a longer growing season. The cultivar Simon has a maturity time more appropriate for southern Nebraska and was observed to be less susceptible to lodging.

Sweet sorghum for ethanol production is considered competitive with grain crops for some criteria, and only with SS cultivar Simon in the environments tested. However, even this cultivar is not competitive with corn and grain sorghum for total or net liquid transportation fuel produced per hectare. Based on GHG emissions, SS may be competitive compared with average corn systems. Gains in SS yield, energy efficiency, and reduced GHG emissions caused by changed management practices are likely to be small. Cultivars with higher sugar yield and/or efficient use of the bagasse (while considering SOC impacts) will be needed to make SS competitive with corn and grain sorghum in ethanol production.

\section{ACKNOWLEDGMENTS}

The authors are grateful to J. Golus, R. Higgins, S. Melvin, J. Petersen, and G. Slater for their technical assistance.

\section{REFERENCES}

Anderson-Teixeira, K.J., S.C. Davis, M.D. Masters, and E.H. Delucia. 2009 Changes in soil organic carbon under biofuel crops. Glob. Chan. Biol. Bioenergy 1:75-96.
Barbanti, L., S. Grandi, A. Vecchi, and G. Venturi. 2006. Sweet and fiber sorghum (Sorghum bicolor (L.) Moench), energy crops in the frame of environmental protection from excessive nitrogen loads. Eur. J. Agron. 25:30-39.

Broadhead, D.M. 1973. Effects of deheading on stalk yield and juice quality of Rio sweet sorghum. Crop Sci. 13:395-397.

Broadhead, D.M. 1974. Effect of planting date and maturity on juice quality of Rio sweet sorghum. Agron. J. 64:389-390.

Broadhead, D.M., and K.C. Freeman. 1980. Stalk and sugar yield of sweet sorghum as affected by spacing. Agron. J. 72:523-524.

Farran, T.B., G.E. Erickson, T.J. Klopfenstein, C.N. Macken, and R.U. Lindquist. 2006. Wet corn gluten feed and alfalfa hay levels in dry-rolled corn finishing diets: Effects on finishing performance and feedlot nitrogen mass balance. J. Anim. Sci. 84:1205-1214.

Ferguson, R.B, G.W. Hergert, and E.J. Penas. 2000. Corn. In R.B. Ferguson (ed.) Nutrient management for agronomic crops in Nebraska. EC 01-155-S. Univ. of Nebraska Coop. Ext., Lincoln.

Ferraris, R., and D.A. Charles-Edwards. 1986. A comparative analysis of the growth of sweet and forage sorghum crops. II. Accumulation of soluble carbohydrates and nitrogen. Aust. J. Agric. Res. 37:513-522.

Geng, S., F.J. Hills, S.S. Johanson, and R.N. Sah. 1989. Potential yields and on-farm ethanol cost of corn, sweet sorghum, fodder beet and sugarbeet. J. Agron. Crop Sci. 162:21-29.

Hunter, E.L., and I.C. Anderson. 1997. Sweet sorghum. Hortic. Rev. 21:73-104.

Klopfenstein, T.J., G.E. Erickson, and V.R. Bremer. 2008. Board-invited review: Use of distillers byproducts in the beef cattle feeding industry. J. Anim. Sci. 86:1223-1231.

Liska, A.J., and R.K. Perrin. 2009. Indirect land use emissions in the life cycle of biofuels: Regulations vs. science. Biofuels Bioproducts Biorefining 3:318-328.

Liska, A.J., H.S. Yang, V.R. Bremer, T.J. Klopfenstein, D.T. Walters, G.E. Erickson, and K.G. Cassman. 2009. Improvements in life cycle energy efficiency and greenhouse gas emissions of corn-ethanol. J. Ind. Ecol. 13:58-74.

Lueschen, W.E., D.H. Putnam, B.K. Kanne, and T.R. Hoversted. 1991. Agronomic practices for production of ethanol from sweet sorghum. J. Prod. Agric. 4:619-625.

Martin, P.M., and F.M. Kelleher. 1984. Effects of row spacing and plant population on sweet sorghum yield. Aust. J. Exp. Agric. Anim. Husb. 24:386-390.

Ricaud, R., and A. Arenneaux. 1990. Sweet sorghum for biomass and sugar production in 1990. Manuscript Rep. Exp. Stn., Louisiana State Univ., St. Gabriel.

Ricaud, R., B. Cochran, A. Arenneaux, and G. Newton. 1979. Sweet sorghum for sugar and biomass production in Lousiana. Manuscript Rep. Exp. Stn., Louisiana State Univ., St. Gabriel.

Smith, G.A., M.O. Bagby, R.T. Lewellan, D.L. Doney, P.H. Moore, F.J. Hills, L.G. Campbell, G.J. Hogaboam, G.E. Coe, and K. Freeman. 1987. Evaluation of sweet sorghum for fermentable sugar production potential. Crop Sci. 27:788-793.

Smith, G.A., and D.R. Buxton. 1993. Temperate zone sweet sorghum ethanol production potential. Bioresour. Technol. 43:71-75.

Staggenborg, S.A., K.C. Dhuyvetter, and W.B. Gordon. 2008. Grain sorghum and corn comparisons: Yield, economics, and environmental responses. Agron. J. 100:1600-1604.

Tarpley, L., S.E. Lingle, D.M. Vietor, D.L. Andrews, and F.R. Miller. 1994. Enzymatic control of nonstructural carbohydrate concentrations in stems and panicles of sorghum. Crop Sci. 33:446-452.

Vermerris, W., C. Rainbolt, D. Wright, and Y. Newman. 2007. Production of biofuel crops in Florida: Sweet sorghum. Available at http://edis.ifas.ufl. edu/AG298; [cited 6 Oct. 2009; verified 25 Nov. 2009]. Univ. of Florida.

Warrick, B.E. 2009. How a sorghum plant develops. Available at http://sanangelo.tamu.edu/agronomy/sorghum/sorghum.htm; [cited 6 Oct. 2009; verified 25 Nov. 2009]. Texas Coop. Ext., Texas A\&M Univ., San Angelo.

Wiendenfeld, R. 1984. Nutrient requirement and use efficiency by sweet sorghum. Energy Agr. 3:49-59.

Wortmann, C.S., A.R. Dobermann, R.B. Ferguson, G.W. Hergert, C.A. Shapiro, and D. Tarkalson. 2006. Fertilizer suggestions for grain sorghum. NebGuide G1669, Univ. of Nebraska, Lincoln. 